\title{
Air displacement plethysmography (pea pod) in full-term and pre-term infants: a comprehensive review of accuracy, reproducibility, and practical challenges
}

\author{
Hajar Mazahery ${ }^{1}$, Pamela R. von Hurst ${ }^{1}$, Christopher J. D. McKinlay ${ }^{2,3}$, Barbara E. Cormack ${ }^{4}$ and Cathryn A. Conlon ${ }^{1 *}$
}

\begin{abstract}
Air displacement plethysmography (ADP) has been widely utilised to track body composition because it is considered to be practical, reliable, and valid. Pea Pod is the infant version of ADP that accommodates infants up to the age of 6 months and has been widely utilised to assess the body composition of full-term infants, and more recently pre-term infants. The primary goal of this comprehensive review is to 1) discuss the accuracy/ reproducibility of Pea Pod in both full- and pre-term infants, 2) highlight and discuss practical challenges and potential sources of measurement errors in relation to Pea Pod operating principles, and 3) make suggestions for future research direction to overcome the identified limitations.
\end{abstract}

Keywords: Air displacement plethysmography, ADP, Pea pod, Infant, Pre-term, Full-term, Body composition

\section{Background}

Early postnatal growth is a major determinant of shortand long-term health outcomes, for both full-term and pre-term infants. The significance of neonatal nutritional management and postnatal growth lies in their effect on infant survival, neurodevelopment and later metabolic function. Postnatal faltering growth is associated with neurodevelopment impairment, especially in preterm infants, and increased risk of cardiometabolic disease, particularly after fetal growth restriction $[1,2]$. Rapid postnatal growth is also associated with increased risk of metabolic syndrome or its determinants [3-7]. These complex effects are influenced by differential growth in soft tissue compartments, namely, fat mass (FM) and lean mass (LM). Growth that involves relatively greater gains in LM appears to be protective for brain development $[8,9]$ and metabolic function [9], whereas accelerated gain in FM, especially centrally and in the first 6 months, is associated with childhood obesity [10]. Preterm infants appear to be particularly susceptible to both postnatal growth failure and central fat deposition [5].

\footnotetext{
* Correspondence: c.conlon@massey.ac.nz

${ }^{1}$ College of Health, Massey University, Auckland 0745, New Zealand Full list of author information is available at the end of the article
}

These observations highlight the importance of assessing body composition and not just total mass when monitoring growth in infants.

There are a number of techniques available to measure body composition in infants, including dual energy $\mathrm{X}$ ray absorptiometry (DXA), bioelectrical impedance analysis (BIA), isotope dilution, magnetic resonance imaging (MRI), and air displacement plethysmography (ADP) [11]. Local FM deposits may also be quantified by ultrasound [12]. ADP has gained popularity due to availability, feasibility and acceptability to parents [13]. ADP utilizes the inverse relationship between pressure and volume in two enclosed chambers - employing the gas law of Boyle and Poisson - that allows for the calculation of body density [14]. A two-compartment model is derived assuming a fixed density of fat $(0.9007 \mathrm{~g} / \mathrm{ml})$ [15] and from age- and sex-specific estimates of fat free mass (FFM) density.

There are two commercially available ADP body composition systems; one for adults (Bod Pod) and one for infants (Pea Pod) (Cosmed, Rome, Italy). While Bod Pod houses both children aged $>2$ years old and adults, Pea Pod accommodates infants from birth until approximately 6 months of age (body weight $\leq 10 \mathrm{~kg}$ ). Recently, Pea Pod 
has also been employed to assess the body composition of pre-term infants from 30 weeks' gestation, and may be a viable method for close monitoring of growth in these infants.

Since the introduction of Pea Pod in 2003 [14, 16, 17] and its validation in 2004 [18], a large number of technical and clinical research papers utilising Pea Pod have been published. Pea Pod has also been included in several recent reviews on body composition, including the utility of ADP technique from infancy to adulthood [19], changes in body composition over the first six months after birth utilising different assessment methods [4, 20], and a comparison of different body composition assessment tools in infancy [11]. However, to our knowledge, no comprehensive review of the use of Pea Pod in both full- and pre-term infants is available.

This review will focus exclusively on studies that have assessed body composition of infants using Pea Pod, including both full- and pre-term infants. We will summarise the published papers, with sections devoted to its accuracy relative to criterion methods, reproducibility, and to practical challenges associated with the use of Pea Pod in clinical settings and studies. From there, we will make suggestions for future research directions to address any identified limitations. At the outset, we present an overview of body composition measures, including assessment of accuracy and reproducibility, following which we describe the results of the review.

\section{Body composition measures}

Body composition may be described using two-, threeand four-compartment models. The two-compartment model [21] divides body weight into FM and FFM (with assumptions made regarding the density of FM and FFM) and ignores the interindividual variation in FFM composition. The three-compartment model [22] is based on measurements of body density and total body water, and assumes a constant mineral to protein ratio in the dry FFM and makes no assumptions about the hydration of FFM. The four-compartment model [23] divides the body weight into fat, water, mineral, and protein, and is the most robust and sensitive to interindividual variability in the composition of FFM. Accordingly, the four-compartment model has less error than other models.

Obesity is defined as an excess of body fat that adversely affects health [20]. Body mass index (BMI, kg/ $\mathrm{m}^{2}$ ) has long been used in clinical practice and epidemiological studies as an indicator of adiposity. However, BMI has been shown to have inconsistent relationship with disease risk and mortality. For example, Nagayama et al. [24] reported an inverse relationship between BMI and cardiometabolic fitness in healthy Japanese adults, whereas Flegal et al. [25] showed that all-cause mortality rate was lower in overweight than normal weight individuals.

This inconsistency may reflect the variable relationship between BMI and adiposity, with the latter being more closely related to disease risk [26]. For example, in a study of 709 adults aged 20-94 years (of both sexes and different ethnicities), Gallagher et al. [26] showed that BMI alone explained only $25 \%$ of the between-individual variability in adiposity. Further, Zeng et al. [27] showed that adiposity, but not BMI, was independently associated with cardiovascular risk factors. Even in normal weight individuals, higher adiposity has been shown to be associated with adverse cardiometabolic health outcomes, such as metabolic syndrome, dyslipidemia, hypertension, and cardiovascular disease [28].

In children, increases in BMI can reflect increases in FFM rather than increases in FM due to the rapid growth of musculoskeletal tissues [29]. A recent systematic review and meta-analysis found that BMI had high specificity but low sensitivity for detection of excess adiposity in children, and thus BMI failed to identify $>25 \%$ of children with excess FM [30]. Hetherington-Rauth et al. [31] compared indirect measures of adiposity (including BMI) with direct measures (DXA FM\% and Fat Mass Index, FMI) in relation to cardiometabolic risk factors in children. Although the authors reported that anthropometric measures performed as well as DXA measures did, addition of direct measures of adiposity to indirect measures may be advantageous for predicting cardiometabolic risk factors such as insulin resistance [31], a finding reported by others [29, 32]. Similarly, in both fullterm and pre-term infants, BMI was shown to have a weak association with FM\% (defined as FM/weight"100) [33, 34], though the relationships were slightly stronger in full-term infants [35]. Thus, in infants and children, BMI appears to be a poor measure of adiposity, and "normal" BMI may still be associated with excess fat mass for size, particularly if LM is low [36].

Adiposity is often referenced to total mass (e.g, wholebody FM\%) but this is statistically problematic given that fat mass is included in both numerator and denominator [37]. As body fat mass increases, FM\% does not increase proportionately (depending on relative growth in FFM), resulting in underestimation of adiposity. The growth velocity of the different soft tissue compartments may be variably affected by nutritional interventions and factors such as age, sex, pubertal status, and ethnicity [38]. To overcome these problems, Van-Itallile [39] advocated referencing of FM and FFM to height squared, giving a FM index (FMI) and FFM index (FFMI), which in adults effectively normalises soft tissue mass for height and allows for comparison between individuals of different size. 
A similar approach has also been recommended in children [40-42], although second order indices may not render soft tissue mass independent of size [40]. This is particularly important when comparing body composition between infants of differing length, especially in pre-term infants whose lower absolute FFM is partly due to their shorter body length. Two studies have reported centiles for FMI and FFMI in the first 6 months after birth, one using DXA in term and preterm infants [35] and the other using Pea Pod in term infants [43]. However, neither study reported if these indices remained correlated with length, so it is unclear if the measures used adequately accounted for differences in body size. This problem can be overcome with the use of sexspecific FM and FFM z-scores for length [40].

\section{Accuracy and reproducibility}

Evaluation of any quantitative assessment technique, including body composition systems, comprises of an examination of its accuracy and reproducibility. Accuracy should be determined against an established criterion method that measures the same physical properties. Hydrostatic weighing is commonly used to validate ADP techniques, but this is not suitable for infants because it requires submerging them in water. Thus, for Pea Pod alternative techniques have been used, including tissue phantoms [17], deuterium dilution [18], DXA [44] and combined techniques with multicompartment models [45].

Tissue phantoms are constructed from animal tissue using fat and muscle compartments, and the composition is usually determined from chemical analysis. DXA is a non-invasive technique that provides whole-body and regional estimates of three main components: bone mineral, bone-free FFM and FM [46]. DXA relies on the differential absorption of $\mathrm{x}$-rays of two different energies and bone edge detection algorithms to calculate bone area and mineral content, and FM and FFM [46]. Isotope dilution, a standard technique for measuring total body water, involves administration of a known dose of isotope to a subject, allowing the isotope to equilibrate and enrich within the body water compartments (including saliva, urine or blood), and then measuring the isotope amount [47]. Isotope serves as a marker for total body water, from which FFM (using a specific hydration factor) and FM can be calculated [46].

Statistically, accuracy is commonly assessed by BlandAltman analysis, [48] which relates the differences between two techniques to the mean value of the measures. Bias is the mean difference between the techniques and $95 \%$ of limits of agreement indicate the possible range of differences between the techniques. Reproducibility of paired measures can also be assessed by Bland-Altman analysis or for multiple measures of the same subject or phantom, by the coefficient of variation, which is the standard deviation as a percentage of the subject or phantom mean value.

\section{Method}

We performed a literature search covering studies published in PubMed from 2003 up to September 2017. Because the first evaluation study of Pea Pod was published in 2003 we limited our search strategy to include papers published after 2003 to September 2017. Key search terms included "air displacement plethysmography" OR "Pea Pod" AND (infant OR infancy). Reviews and non-English papers were excluded. We also excluded papers that included non-human species. However, those studies that used animal species to investigate the accuracy/reproducibility of Pea Pod were included.

\section{Results}

Our literature search identified 141 papers, including 13 non-human studies, three non-English papers, and 17 reviews, leaving 108 papers for title and abstract checking. Of these, 26 papers were excluded because they referred to Bod Pod $(n=7)$, reported a study protocol $(n=5)$, or were unrelated to Pea Pod $(n=14)$. Thus 82 papers were included in the final review, two of which were accuracy studies using animal tissues and live animals, four were accuracy/reproducibility studies in full-term infants, two were accuracy/reproducibility studies in pre-term infants, and 74 were clinical studies using Pea Pod to assess the body composition of either full-term infants, pre-term infants or both (Fig. 1). Characteristics of included validation studies are presented in Table 1.

\section{Accuracy and reproducibility of pea pod Studies using animal tissues and/or live animals}

Accuracy As part of the development of Pea Pod, Sainz and colleagues [17] were the first to evaluate the accuracy of Pea Pod against chemical analysis and hydrostatic weighing of 24 bovine tissue phantoms, and to assess its potential use in paediatric body composition assessment. Tissue phantom mass (1.39 to $9.95 \mathrm{~kg}$ ) and fat content (2.1\% to $34.4 \%)$ approximated that of infants between birth and six months of age. Compared with chemical analysis, the bias for FM\% was $-0.04 \%$ and was constant across the FM\% range (indicating no systematic bias), and the $95 \%$ limits of agreement were $-1.22 \%$ to $1.13 \%$. Frondas-Chauty et al. [44] compared Pea Pod measures of FM\% with biochemical analysis in 12 piglets at 2 to 21 days of age (weight range 1.03 to $8.49 \mathrm{~kg}$ ). BlandAltman analysis showed $95 \%$ limits of agreement from $-4 \%$ to $3 \%$. 


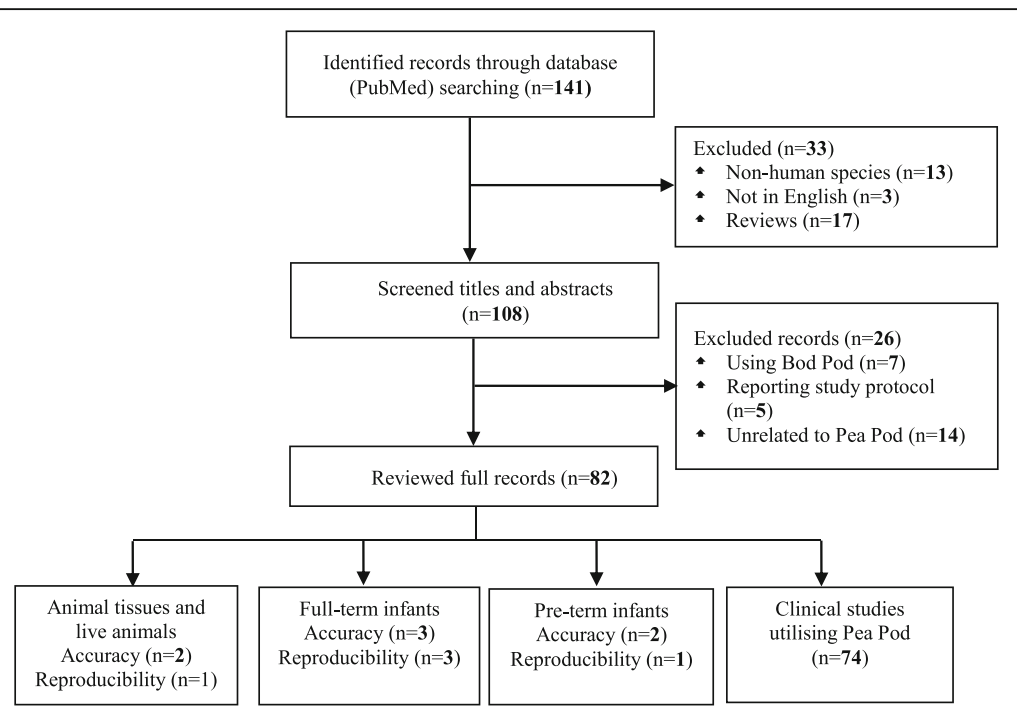

Fig. 1 Flow diagram of study selection process

Reproducibility Frondas-Chauty et al. also evaluated the reproducibility of Pea Pod in piglets (four measurements within one hour) [44]. Reproducibility was limited at low FM\% (CV 14\% to 32\% at mean FM\% of 3.7\%) but better at higher FM\% (CV $4 \%$ to $10 \%$ at mean $\mathrm{FM} \%$ of $11.7 \%)$.

In summary, these studies suggest that Pea Pod has reasonable accuracy and reproducibility for FM\% but reproducibility may be poor with lean body composition.

\section{Studies in full-term infants}

The accuracy and reproducibility of Pea Pod was examined in full-term infants by three studies each. All studies included both male and female infants. The accuracy studies included between 49 to 84 infants and the reproducibility studies from 17 to 36 . The chronological age ranged from 0.4 to 24.6 weeks. The behavioural states $[16,18]$ and ethnicity $[18,45]$ were considered in two studies.

Accuracy Ma et al. [18] examined the accuracy of Pea Pod measures of FM\% against deuterium dilution in full-term infants aged 0.4 to 24.4 weeks and weighing 2 . 7 to $7.4 \mathrm{~kg}$. Limits of agreement (95\%) for FM\% were relatively wide $(-6.84 \%$ to $6.71 \%)$. The authors reported that the results were not influenced by infant behavioural state. Ellis et al. [45] evaluated Pea Pod against a four-compartment model in full-term infants at 2 to 17 weeks of age. There was no bias for FM\% but the $95 \%$ limits of agreement were also wide $(-6.8 \%$ to $8.1 \%)$. In multiple regression analysis that included protein and hydration fractions, the mineral fraction of FFM was the only significant factor associated with differences in FM\% between Pea Pod and the four-compartment reference model $\left(\mathrm{R}^{2} 16 \%, P=0.004\right)$. Fields et al. [49] compared Pea Pod and DXA in 84 full-term infants at 6 months of age. There was bias for FM\% of $-4 \%$ and $95 \%$ limits of agreement of $-8 \%$ to $0 \%$. However, the bias was positively related to FM\%, suggesting underestimation of FM\% in infants with lower fat content.

Reproducibility The reproducibility (within and between days) of Pea Pod was examined in three studies $[16,18,45]$. Yao et al. studied 17 full-term infants aged between 1.4 to 21.7 weeks and reported that reproducibility was not affected by the infants' behavioural state, body weight, urination, defecation, or FM\% [16]. The within and between day 95\% limits of agreement for FM\% were -2.0 to 1.2 and -2.2 to 1.7 , respectively. Similarly, Ma et al. found that in infants aged between 0 . 4 to 21.7 weeks, $95 \%$ limits of agreement for between day differences in $\mathrm{FM} \%$ were $-2.9 \%$ and $1.9 \%$, and the within subject CV for FM\% was 4.9\% [18]. Reproducibility was not influenced by infants' behavioural state (awake and active, $N=147$; crying intensely, $N=74$; urination during the measurement, $N=33$ ) or ethnicity (Asians, $N=20$; white, $N=16$ ). Finally, Ellis et al. [45] reported within day $95 \%$ limits of agreement for $\mathrm{FM} \%$ of $-2.3 \%$ to $3.1 \%$ in 31 infants at a mean age of 6 weeks.

In summary, Pea Pod has reasonable reproducibility for FM\% in full-term infants but only modest accuracy, with overestimation or underestimation of FM\% by $6 \%$ to $8 \%$. Although one DXA study suggested that Pea Pod systematically underestimates FM\%, this not seen when referenced to other criterion measures. Studies included very few infants in the first week of life, so accuracy and reproducibility of Pea Pod in early neonatal period is unclear. Further, there are no data on the reproducibility 
Table 1 Accuracy and reproducibility studies of Pea Pod in full-term and preterm infants

\begin{tabular}{|c|c|c|c|c|c|c|c|}
\hline Reference & Country & $\begin{array}{l}\text { Comparison } \\
\text { methods }\end{array}$ & $\begin{array}{l}\text { Inclusion/ } \\
\text { Exclusion }\end{array}$ & Number (sex) & $\begin{array}{l}\text { Number } \\
\text { of tests }\end{array}$ & $\begin{array}{l}\text { Age at } \\
\text { measurement }\end{array}$ & Results \\
\hline \multicolumn{8}{|c|}{ Animal and Animal Tissues } \\
\hline \multicolumn{8}{|c|}{ Accuracy studies } \\
\hline $\begin{array}{l}\text { Sainz et } \\
\text { al. (2003) } \\
{[17]}\end{array}$ & The US & $\begin{array}{l}\text { ADP, chemical analysis } \\
\text { (CA), hydrostatic weighing }\end{array}$ & $\begin{array}{l}\text { Bovine tissue with wide ranges of mass } \\
(1.39-9.95 \mathrm{~kg}) \text { and FM\% (2.08-34.40\%) }\end{array}$ & $\begin{array}{l}24 \text { bovine } \\
\text { tissue } \\
\text { phantoms } \\
\text { (NA) }\end{array}$ & NR & NA & $\begin{array}{l}\text { \%Fat: ADP: } 18.55 \% \\
\text { CA: } 18.59 \% \\
\text { SD \%fat ADP: } 0.70 \% \\
\text { CA: } 0.73 \% \\
\text { 95\% LoA: }-1.22-1.13 \% \text { Fat }\end{array}$ \\
\hline $\begin{array}{l}\text { Frondas- } \\
\text { Chauty et } \\
\text { al. (2012) } \\
{[44]}\end{array}$ & France & ADP, chemical analysis & $\begin{array}{l}\text { Live piglets with wide ranges of mass } \\
(1.03-8.49 \mathrm{~kg}) \text { and FM\% }(3.2-16.4 \%)\end{array}$ & 34 live piglets & NR & $\begin{array}{l}2,7, \text { and } \\
21 \text { days }\end{array}$ & $\begin{array}{l}\text { \%Fat: Pea Pod, } 8.01 \pm 4.03 \% \text {; } \\
\text { CA, } 8.7 \pm 4.1 \% \\
\text { Standard error of the } \\
\text { estimate: } 1.7 \% \\
R^{2}: 0.83\end{array}$ \\
\hline \multicolumn{8}{|c|}{ Reproducibility studies } \\
\hline $\begin{array}{l}\text { Frondas- } \\
\text { Chauty et } \\
\text { al. (2012) } \\
{[44]}\end{array}$ & France & ADP within a day & Live piglets (aa above) & 34 live piglets & $\begin{array}{l}\text { Four } \\
\text { times }\end{array}$ & $\begin{array}{l}2,7 \text {, and } \\
21 \text { days }\end{array}$ & $\begin{array}{l}\text { CV: ranging from } 2.2 \text { to } \\
44.1 \% \\
\text { Root mean square CV: } 17.9 \% \\
\text { CV values and median } \\
\text { differed by age and \%fat } \\
\text { assessed using CA, with less } \\
\text { variability in piglets with } \\
\text { higher \%fat }\end{array}$ \\
\hline
\end{tabular}

\section{Full-Term Infants}

\section{Accuracy studies}

Ma The US ADP, deuterium dilution
et al.
(2004)
[18] China
$\quad$ Ellis The US ADP, 4-CM
et al.
(2007)

[45]

The US Pea Pod, DXA

Fields et

al. (2012)

[49]

Reproducibility studies

$\begin{array}{ll}\text { Yao The US } & \begin{array}{l}\text { ADP within and between- } \\ \text { days - data from multiple }\end{array} \\ \text { et al. } & \begin{array}{l}\text { compartment studies of } \\ \text { (2003) } \\ \text { [16] } \\ \text { Butte et al. and Fomon et } \\ \text { al }\end{array}\end{array}$

Ma The US ADP within and between
et al. $\quad$ \& China days
(2004)

[18]
Healthy $f$ ull-term infants

(mixed ethnicity; white and Chinese)

Full term healthy infants (mixed ethnic groups; white, African American, Hispanic American)

Full term singleton infants, average for gestational age and with gestational age > $=37$, staying in hospital less than 3 days after delivery. nfants with congenital malformation were excluded. (ethnicity nor reported)

Full term healthy infants with weight ranging between $3.40-7.45 \mathrm{~kg}$ and age ranging between $1.40-21.70$ weeks (ethnicity not reported)
Healthy full-term infants (mixed ethnicity; white and (hinese)
$17(8 \mathrm{~F}, 9 \mathrm{M}) \quad \begin{aligned} & 2 \text { days } \\ & \text { and } 2 \\ & \text { tests per } \\ & \text { only one } \\ & \text { day }\end{aligned}$

Full term healthy infants (mixed ethnic groups; white, African American, Hispanic American)
Preterm singleton infants with gestational age $=<36$ weeks were included. Also term infants with gestational age $>=37$ were
5.8 (6.0) (0.4- \%fat Pea Pod: 20.32-6.87\%; 24.4) wks

deuterium: $20.39-6.68$ 95\% LoA: - 6.84-6.71\% (not related to body mass)

$8.0(5.4)$ wks

Fat Pea Pod: 16.9 (6.5) 4-CM: 16.3 (7.2) $(P=0.62)$ 95\% LoA: $-6.8-8.1 \%$

6 mo; $168.4 \quad$ \%Fat Pea Pod: 26.7 (4.7) (3.8) days DXA: $31.3(3.6),(P<0.001)$
(2007)

[45]

Pre-Term Infants

\section{Accuracy studies}

$\begin{array}{ll}\text { Roggero Italy } & \begin{array}{l}\text { Pea Pod, deuterium } \\ \text { dilution }\end{array}\end{array}$

et al.

(2012)
$36(16 \mathrm{~F}, 20 \mathrm{M}) \quad 2$ days and 2 tests on first day

$1.40-21.70$
weeks (all 3
tests);

$7.6(7.2)(0.4-$ 21.7) wks

$\begin{array}{ll} & \text { and } 2 \\ \text { tests on } & \\ \text { first day } & \end{array}$

$31(18 \mathrm{~F}, 13 \mathrm{M}) \quad$ Twice $\quad 6.0(3.3) \mathrm{wks}$

$$
\begin{aligned}
& \text { SD \%fat within: } 0.7 \% \\
& \text { CV \%fat within: } 7.9 \%
\end{aligned}
$$

95\% LoA: - 2.3-3.1\%

\%fat: ranging 7.49-32.08\% \%Fat within day: 0.52 between day: 0.60 CV \%fat within day: 2.85 ; between day: 2.95 95\% LoA within day: - 2.0-1.2\%; between day: behavioural state)

\% fat within day: 0.69\% between day: $0.72 \%$ CV \%fat within day: 4.94; between day: $5.10 \%$ 95\% LoA within day: - 2.7-3.1\%; between day: $-2.9-1.9$ (not a function of body $f$ atness) \%fat Pea Pod: 5.67 (1.84), deuterium dilution: 5.99 (2.56), $P=0.53$ 95\% LoA: $-3.4-2.76 \%$ 
Table 1 Accuracy and reproducibility studies of Pea Pod in full-term and preterm infants (Continued)

\begin{tabular}{|c|c|c|c|c|c|c|c|}
\hline Reference & Country & $\begin{array}{l}\text { Comparison } \\
\text { methods }\end{array}$ & $\begin{array}{l}\text { Inclusion/ } \\
\text { Exclusion }\end{array}$ & Number (sex) & $\begin{array}{l}\text { Number } \\
\text { of tests }\end{array}$ & $\begin{array}{l}\text { Age at } \\
\text { measurement }\end{array}$ & Results \\
\hline [50] & & & $\begin{array}{l}\text { included. Infants aged }>1 \text { mo of age, with } \\
\text { congenital diseases, } \\
\text { chromosomal abnormalities, respiratory } \\
\text { distress syndrome, or severe brain, } \\
\text { metabolic, cardiac, or gastrointestinal } \\
\text { diseases were excluded. }\end{array}$ & & & & $\begin{array}{l}\text { (not a function of mean } \\
\text { values) }\end{array}$ \\
\hline $\begin{array}{l}\text { Forsum } \\
\text { et al. } \\
\text { (2016) } \\
{[51]}\end{array}$ & Sweden & $\begin{array}{l}\text { Pea Pod, deuterium } \\
\text { dilution }\end{array}$ & $\begin{array}{l}\text { Infants without sepsis or malformations } \\
\text { born between } 32 \text { and } 37 \text { gestational weeks } \\
\text { (ethnicity not reported) }\end{array}$ & $14(4 \mathrm{~F}, 10 \mathrm{M})$ & NR & 3-7 days old & $\begin{array}{l}\text { \%Fat Pea Pod: } 4.2(3.9), \\
\text { deuterium dilution } 3.2(3.8) \\
(P>0.05) \\
95 \% \text { LoA: }-6.8-4.8 \% \\
\text { FFM density by Pea Pod did } \\
\text { not correlate with those of } \\
\text { deuterium dilution }\left(r^{2}=0.04\right. \\
P>0.05) \\
\text { Hydration factor: } 83 \%\end{array}$ \\
\hline \multicolumn{8}{|c|}{ Reproducibility studies } \\
\hline $\begin{array}{l}\text { Roggero } \\
\text { et al. } \\
\text { (2012) } \\
{[50]}\end{array}$ & Italy & NA & $\begin{array}{l}\text { Preterm singleton infants with gestational } \\
\text { age }=<36 \text { weeks were included. Also term } \\
\text { infants with gestational age }>=37 \text { were } \\
\text { included. Infants aged }>1 \text { mo of age, with } \\
\text { congenital diseases, } \\
\text { chromosomal abnormalities, respiratory } \\
\text { distress syndrome, or severe brain, } \\
\text { metabolic, cardiac, or gastrointestinal } \\
\text { diseases were excluded. }\end{array}$ & $\begin{array}{l}\text { Precision: } \\
57(29 \mathrm{~F}, 28 \mathrm{M}) \\
\text { Inter-devise } \\
\text { reproducibility: } \\
9 \text { full term } \\
\text { and } 3 \text { preterm } \\
(6 \mathrm{~F}, 6 \mathrm{M})\end{array}$ & Twice & $<1$ month & $\begin{array}{l}\text { \%Fat SD: } 1.1 \\
95 \% \text { LoA: }-2.05-2.36 \% \\
\text { Inter-device } \\
\text { reproducibility: } \\
\text { \%fat test 1: } 8.97 \% \text {, test 2: } \\
8.55 \% \\
95 \% \text { LoA: }-1.87-2.71\end{array}$ \\
\hline
\end{tabular}

NA, not applicable; $A D P$, air displacement plethysmography; $C A$, chemical analysis; $S D$, standard deviation; LoA, limits of agreement; wks, weeks; US, united states; $C V$, coefficient of variation; 4-CM, 4 compartment model; $D X A$, dual energy $X$-ray absorptiometry

and accuracy specifically in infants born small, large or appropriate for gestational age.

\section{Studies in pre-term infants}

Accuracy Only two studies have specifically evaluated the accuracy of Pea Pod in pre-term infants, both using isotope dilution (Table 1) $[50,51]$. Roggero et al. referenced Pea Pod with a two-compartment model and included 10 pre-term infants ( $\leq 36$ weeks) aged less than one month with mean (SD) weight of $1.83(0.21) \mathrm{kg}$ [50]. The 95\% limits of agreement for FM\% were $-3.4 \%$ to $2.8 \%$ with no bias [50]. Forsum et al. [51] measured 14 pre-term infants at 32 to 35 weeks of gestation in the first week with a mean (SD) weight of $2.04(0.33) \mathrm{kg}$. Compared to a threecompartment model, the $95 \%$ limits of agreement were relatively wide ( $-6.8 \%$ to $4.8 \%$ ) but there was no bias. This study also showed that at higher FFM density, Pea Pod underestimated FFM density.

Reproducibility Roggero et al. [50] performed two consecutive Pea Pod measurements in 57 infants and the $95 \%$ limits of agreement were $-2.05 \%$ and $2.36 \%$. They also compared measurements in 12 infants (3 preterm) using two Pea Pod devices in the same room and the inter-device $95 \%$ limits of agreement were $-1.87 \%$ and $2.71 \%$.
In summary, there are few data on the validity of Pea Pod in preterm infants, but performance appears to be similar to full-term infants, that is, reasonable reproducibility but only modest accuracy.

\section{Practical challenges of pea pod}

Despite the above concerns about accuracy, Pea Pod has been considered a valuable tool with a broad clinical research application. We identified 74 papers utilising Pea Pod to answer research questions, including studies comparing different clinical groups (pre-term vs. fullterm infants, small for gestational age vs. appropriate for gestational age, different ethnicities, different feeding methods and breast milk compositions, and different health status or health indicators) [33, 52-69], assessing growth charts, to cross-validate FM values obtained by other techniques and anthropometric measures (e.g. skinfold) [70-76], monitoring growth patterns [54, 7780], investigating the relationship between maternal and prenatal factors and health outcomes during infancy [81-86], and others [87]. The majority of these studies $(n=43)$ included only full-term infants [33, 52-54, 56$58,60,62,66,67,69-72,74,75,78,80,81,83-86,88-$ 106], 13 only pre-term infants $[9,68,73,77,79,107-$ $112]$, and 17 both full- and pre-term infants [55, 59, 61, 63-65, 76, 82, 87, 113-120]. Although, the use of Pea Pod in both full-term and pre-term infants and in specific clinical risk and ethnic groups is feasible, it might 
be associated with some practical challenges. Herein, we highlight and discuss potential challenges associated with the use of Pea Pod.

Measuring body composition in Pea Pod involves the simultaneous weighing and measuring of length and body volume. Pea Pod assesses body composition considering an infant's anthropometric and demographic characteristics that are entered in to the Pea Pod system by personnel. As weight changes dramatically during early infancy, this information should be obtained consecutively with the Pea Pod test. Per the manufacturer manual, it is advised to conduct the Pea Pod test in duplicate to potentiate the accuracy. Repeat measures in infants might be associated with practical challenges and might require a third test which increases both researcher and caregiver burden. Out of 73 papers utilising Pea Pod, 13 reported repeated measurements, six of which reported duplicate tests [62, 67, 76, 85, 112, 114], six reported a third test if the results of the first two differed significantly $[81,102,105,116,117,120]$, and one reported three tests (performed on all subjects) [115], and the remaining studies that did not duplicate did not provide a rationale.

Furthermore, body moisture, temperature, and hair have been shown to significantly influence FM\%, and underestimate it by $2 \%[121,122]$. Thus, Pea Pod testing should always be conducted at a moisture free and normal body temperature prior to measurement and in a resting state while wearing wig cap or smoothed hair using baby oil. Reproducibility studies have not suggested any effect of infant movement, crying, urination and defecation on the body composition measurements $[18,45]$, although the data are few.

The calibration process requires the placement of a hollow cylinder with known mass and volume into the Pea Pod. Mass and volume calibration should also be adjusted for any objects attached to the infants, which is mainly true for those remaining in hospital. Objects such as name bracelets and cord clamps affect body mass and volume readings and consequently FM and FFM. Some but not all studies reported adjusting for these objects [53, 58, 72, 76, 80, 89, 90, 98, 108]. Ramel et al. [108] also adjusted for other objects such as nasogastric tube and oximetry monitor.

Assessment of body composition by Pea Pod is not suitable for all infants. For example, Pea Pod is limited to infants weighing from $1 \mathrm{~kg}$ to $10 \mathrm{~kg}$ and with body volume $>1.85 \mathrm{~L}$ [14]. Infants who require oxygen, intravenous fluids and who are unstable also cannot easily undergo Pea Pod measurement. The inclusion/exclusion criteria of a large number of papers are based on these characteristics such as weight $[9,43,55,65,71,73,78$, $79,88,93,108-111,113,114]$ and health condition [9, $33,54,61,76,77,98,100,112,123])$.
Pea Pod accommodates infants weighing up to $10 \mathrm{~kg}$ (approximately six months of age), but the child and adult version of ADP (Bod Pod) only houses children aged $\geq 2$ years. Unfortunately, use of ADP for the measurement of body composition in children aged 6 to 24 months has been shown to be inaccurate [124]. This leaves a large gap, from 6 months to 2 years, where body composition cannot be determined using ADP method. This is an important consideration for longitudinal research projects and may limit the applicability of ADP.

When infants with very low body fat content are measured in Pea Pod, the system may give errors and even a negative body fat content that is not physiologically plausible. Low body fat or negative body fat errors were reported in three studies $[43,80,88]$, two of which were from Ethiopia [42, 76], in which 30 and 14 infants had to be excluded, respectively, and one from Australia [80], in which one infant was excluded. Similarly, spuriously high body fat content has also been reported in two studies [76, 80]. Carrberry et al. [80] reported excluding one infant - whose father was of Tongan ethnicity - due to a very high FM\%, and Villar et al. [76] excluded three infants due to high FM\% or FFM\% ( $>3$ SD). These findings highlight the importance of considering measurement errors in preliminary sample size calculation by study investigators, particularly if a multiethnic population is under the investigation.

ADP devices operate under changing air temperature; for example, as an individual enters the test chamber the air temperature in the test chamber increases, resulting in different compressibility (adiabatic). However, the air in the thoracic cavity and near the surface of skin is isothermic and thus is more easily compressed (40\%) than an equivalent volume of adiabatic air [125], which can affect FM readings. In adult ADP devices, thoracic gas volume is measured directly, but this is impractical in infants and young children. Thus, the thoracic gas volume is predicted based on infant weight, length and age. The prediction equation has been validated in full-term infants [126, 127], but its accuracy in pre-term infants and those with lung disease is unknown. Accordingly, Pea Pod measurements in infants with lung disease should be interpreted with caution because of altered thoracic gas volume.

To account for the skin surface artefact, the system software applies a correction factor based on body surface area. Body surface estimates are less accurate at the extremes of body size [128]. This might have implications for studies involving pre-term and growth restricted infants, and those born large for gestational age, such as with maternal diabetes.

The Pea Pod system calculates FM from body weight, volume and the density of FM and FFM. It is well documented that the density of fat mass is constant at 0 . $9007 \mathrm{~g} / \mathrm{ml}$, though the density of FFM varies with age 
and physiological state. The FFM density estimates use in Pea Pod are derived from full-term infants [129]. Fomon et al. based their model on the measurements of protein, minerals and water in FFM [129], and Butte et al. on the measurements of body weight, body protein, bone minerals, and body water [130]. An important difference between these two models is the estimated amount of water (hydration factor) in FFM, which is lower in the Fomon model, specifically in the neonatal period $(80.6 \%$ for both boys and girls at birth; $82.7 \%$ for boys and $83.1 \%$ for girls at two weeks, respectively) $[129,130]$. Thus the Fomon model may produce FM values that are greater than those obtained using the Butte model. For example, Eriksson [91] reported a greater increase in FM\% between one and 12 weeks of age when using the Butte model than the Fomon model. Consideration of the FFM model is important in longitudinal research $\mathrm{i}$ and when comparing results from different studies.

The hydration factor of FFM changes considerably during early infancy (particularly in pre-term infants) and can affect estimates of FFM and FM [131]. The Pea Pod system has algorithms to account the fluctuation in hydration in this period of life [51]. However, Forsum et al. [51] found that when compared to a three compartment model using isotope dilution, Pea Pod gave biased values for predicted FFM density in moderately pre-term infants (lower by $0.0019 \pm 0.0058 \mathrm{~g} / \mathrm{ml}$ ). Biological variability in hydration factors may lead to variations in FFM density and consequently inaccurate body composition readings.

\section{Conclusion and future lines of research}

Pea Pod is a convenient a way to measure body composition in infants and may be useful for monitoring groups of infants but appears to have only modest accuracy in individual subjects. Multiple factors may affect accuracy, including body moisture and temperature, objects attached to infants, extremes of body size, thoracic gas prediction equations, FFM density, and fluctuations in FFM hydration factor. There are few data on the accuracy of Pea Pod in preterm infants and a reference body composition for pre-term infants is lacking. Further, the validity of Pea Pod in different clinical risk groups and ethnicities is unknown. Given these gaps in the current literature, the following are suggested as future lines of research:

1) Further validate pea pod in infants against the gold standard four compartment model, especially in pre-term infants and in more diverse populations.

2) Investigate the accuracy/reproducibility of Pea Pod in different birth weight for gestational age categories.

3) Investigate the impact of FFM hydration level and density in Pea Pod measurements.
4) Develop and validate specific prediction equations to estimate thoracic cavity gas in pre-term infants and more diverse infant populations.

5) Investigate the impact of body movement, urination, defecation, and lung disease on Pea Pod measurements.

6) Develop and design equipment working on the ADP principles that could accommodate children aged 6-24 months to support longitudinal research.

7) Develop a set of recommendations for complete and transparent reporting of study procedures when using Pea Pod.

8) Investigate the best body composition measure(s) that accurately predicts growth, nutritional status, obesity and health outcomes.

9) Establish body composition reference data or curves for both full-term and pre-term infants, such as FM/FFM for length $\mathrm{z}$-scores.

\section{Abbreviations}

4-CM: 4 Compartment Model; ADP: Air displacement plethysmography; BIA: Bioelectrical Impedance Analysis; BMI: Body Mass Index; CR: Chemical Analysis; CV: Coefficient of variation; DXA: Dual Energy X-ray Absorptiometry; FFM: Fat Free Mass; FFMI: Fat Free Mass Index; FM: Fat Mass; FMI: Fat Mass Index; LM: Lean Mass; LoA: Limits of Agreement; MRI: Magnetic Resonance Imaging; NA: Not Applicable; NR: Not Reported; SD: Standard Deviation; US: United States

\section{Acknowledgements}

Not applicable.

Funding

Not applicable.

\section{Availability of data and materials}

Data sharing is not applicable as no new datasets were generated or analysed for this review.

\section{Authors' contributions}

CAC and HM conceived the manuscript idea, HM researched and drafted the manuscript, CJDM, PRvH, BEC, and CAC reviewed and approved the final manuscript.

Ethics approval and consent to participate

Not applicable.

\section{Consent for publication}

Not applicable.

\section{Competing interests}

The authors declare that they have no competing interests.

\section{Publisher's Note}

Springer Nature remains neutral with regard to jurisdictional claims in published maps and institutional affiliations.

\section{Author details}

${ }^{1}$ College of Health, Massey University, Auckland 0745, New Zealand. ${ }^{2}$ Kidz First Neonatal Care, Counties Manukau Health, Auckland, New Zealand.

${ }^{3}$ Liggins Institute and Department of Paediatrics: Child and Youth Health, University of Auckland, Auckland, New Zealand. ${ }^{4}$ Starship Children's Hospital, Auckland District Health Board, Auckland, New Zealand. 


\section{Received: 13 November 2017 Accepted: 20 March 2018} Published online: 20 June 2018

\section{References}

1. Eriksson JG, Osmond C, Kajantie E, Forsen TJ, Barker DJ. Patterns of growth among children who later develop type 2 diabetes or its risk factors. Diabetologia. 2006;49(12):2853-8.

2. Osmond C, Barker DJ, Winter PD, Fall CH, Simmonds SJ. Early growth and death from cardiovascular disease in women. BMJ. 1993;307(6918):1519-24.

3. Franz AR, Pohlandt F, Bode H, Mihatsch WA, Sander S, Kron M, et al. Intrauterine, early neonatal, and postdischarge growth and neurodevelopmental outcome at 5.4 years in extremely preterm infants after intensive neonatal nutritional support. Pediatrics. 2009;123(1):e101-9.

4. Corpeleijn WE, Kouwenhoven SM, van Goudoever JB. Optimal growth of preterm infants. World Rev Nutr Diet. 2013;106:149-55.

5. Hemachandra AH, Howards PP, Furth SL, Klebanoff MA. Birth weight, postnatal growth, and risk for high blood pressure at 7 years of age: results from the collaborative perinatal project. Pediatrics. 2007;119(6):e1264-70.

6. Kerkhof GF, Willemsen RH, Leunissen RW, Breukhoven PE, Hokken-Koelega AC. Health profile of young adults born preterm: negative effects of rapid weight gain in early life. J Clin Endocrinol Metab. 2012;97(12):4498-506.

7. Ong KK, Kennedy K, Castaneda-Gutierrez E, Forsyth S, Godfrey KM, Koletzko $B$, et al. Postnatal growth in preterm infants and later health outcomes: a systematic review. Acta Paediatr. 2015;104(10):974-86.

8. Ramel SE, Gray HL, Christiansen E, Boys C, Georgieff MK, Demerath EW Greater early gains in fat-free mass, but not fat mass, are associated with improved neurodevelopment at 1 year corrected age for prematurity in very low birth weight preterm infants. J Pediatr. 2016;173:108-15.

9. Pfister KM, Gray HL, Miller NC, Demerath EW, Georgieff MK, Ramel SE. Exploratory study of the relationship of fat-free mass to speed of brain processing in preterm infants. Pediatr Res. 2013;74(5):576-83.

10. Ay L, Hokken-Koelega AC, Mook-Kanamori DO, Hofman A, Moll HA, Mackenbach JP, et al. Tracking and determinants of subcutaneous fat mass in early childhood: the generation R study. Int J Obes. 2008;32(7):1050-9.

11. Demerath EW, Fields DA. Body composition assessment in the infant. Am J Hum Biol. 2014;26(3):291-304

12. De Lucia Rolfe E, Modi N, Uthaya S, Hughes IA, Dunger DB, Acerini C, et al. Ultrasound estimates of visceral and subcutaneous-abdominal adipose tissues in infancy, J Obes. 2013:2013:9.

13. Lingwood BE. Bioelectrical impedance analysis for assessment of fluid status and body composition in neonates-the good, the bad and the unknown. Eur J Clin Nutr. 2013;67(Suppl 1):S28-33.

14. Urlando A, Dempster $P$, Aitkens S. A new air displacement plethysmograph for the measurement of body composition in infants. Pediatr Res. 2003:53(3):486-92.

15. Fidanza F, Keys A, Anderson JT. Density of body fat in man and other mammals. J Appl Physiol. 1953;6(4):252-6.

16. Yao M, Nommsen-Rivers L, Dewey K, Urlando A. Preliminary evaluation of a new pediatric air displacement plethysmograph for body composition assessment in infants. Acta Diabetol. 2003;40(Suppl 1):S55-8.

17. Sainz RD, Urlando A. Evaluation of a new pediatric air-displacement plethysmograph for body-composition assessment by means of chemical analysis of bovine tissue phantoms. Am J Clin Nutr. 2003;77(2):364-70.

18. Ma G, Yao M, Liu Y, Lin A, Zou H, Urlando A, et al. Validation of a new pediatric air-displacement plethysmograph for assessing body composition in infants. Am J Clin Nutr. 2004;79(4):653-60.

19. Fields DA, Gunatilake R, Kalaitzoglou E. Air displacement plethysmography: cradle to grave. Nutr Clin Pract. 2015;30(2):219-26.

20. Gianni ML, Roggero P, Orsi A, Piemontese P, Garbarino F, Bracco B, et al. Body composition changes in the first 6 months of life according to method of feeding. J Hum Lact. 2014;30(2):148-55.

21. Brozek J, Grande F, Anderson JT, Keys A. Densitometric analysis of body composition: revision of some quantitative assumptions. Ann N Y Acad Sci. 1963:110:113-40.

22. Withers RT, Laforgia J, Heymsfield SB. Critical appraisal of the estimation of body composition via two-, three-, and four-compartment models. Am J Hum Biol. 1999;11(2):175-85.

23. Fuller NJ, Jebb SA, Laskey MA, Coward WA, Elia M. Four-component model for the assessment of body composition in humans: comparison with alternative methods, and evaluation of the density and hydration of fat-free mass. Clin Sci (Lond). 1992;82(6):687-93.
24. Nagayama D, Imamura $H$, Sato $Y$, Yamaguchi $T$, Ban N, Kawana $H$, et al. Inverse relationship of cardioankle vascular index with BMl in healthy Japanese subjects: a cross-sectional study. Vasc Health Risk Manag. 2017;13: $1-9$.

25. Flegal KM, Kit BK, Orpana H, Graubard BI. Association of all-cause mortality with overweight and obesity using standard body mass index categories: a systematic review and meta-analysis. JAMA. 2013;309(1):71-82.

26. Gallagher D, Visser M, Sepulveda D, Pierson RN, Harris T, Heymsfield SB. How useful is body mass index for comparison of body fatness across age, sex, and ethnic groups? Am J Epidemiol. 1996;143(3):228-39.

27. Zeng Q, Dong S-Y, Sun X-N, Xie J, Cui Y. Percent body fat is a better predictor of cardiovascular risk factors than body mass index. Braz J Med Biol Res. 2012;45(7):591-600.

28. Romero-Corral A, Somers VK, Sierra-Johnson J, Korenfeld Y, Boarin S, Korinek J, et al. Normal weight obesity: a risk factor for cardiometabolic dysregulation and cardiovascular mortality. Eur Heart J. 2010;31(6):737-46.

29. Lawlor DA, Benfield L, Logue J, Tilling K, Howe LD, Fraser A, et al. Association between general and central adiposity in childhood, and change in these, with cardiovascular risk factors in adolescence: prospective cohort study. BMJ. 2010;341:c6224.

30. Javed A, Jumean M, Murad MH, Okorodudu D, Kumar S, Somers VK, et al. Diagnostic performance of body mass index to identify obesity as defined by body adiposity in children and adolescents: a systematic review and meta-analysis. Pediatr Obes. 2015;10(3):234-44

31. Hetherington-Rauth M, Bea JW, Lee VR, Blew RM, Funk J, Lohman TG, et al. Comparison of direct measures of adiposity with indirect measures for assessing cardiometabolic risk factors in preadolescent girls. Nutr J. 2017;16:15.

32. Addo OY, Himes JH. Are field measures of adiposity sufficient to establish fatness-related linkages with metabolic outcomes in adolescents? Eur J Clin Nutr. 2014:68(6):671-6.

33. De Cunto A, Paviotti G, Ronfani L, Travan L, Bua J, Cont G, et al. Can body mass index accurately predict adiposity in newborns? Arch Dis Child Fetal Neonatal Ed. 2014;99(3):F238-9.

34. Cooke RJ, Griffin I. Altered body composition in preterm infants at hospital discharge. Acta Paediatr. 2009;98(8):1269-73.

35. Goswami I, Rochow N, Fusch G, Liu K, Marrin ML, Heckmann M, et al. Length normalized indices for fat mass and fat-free mass in preterm and term infants during the first six months of life. Nutrients. 2016;8(7):417.

36. Wells JC. A critique of the expression of paediatric body composition data. Arch Dis Child. 2001;85(1):67-72

37. Wells JCK. Toward body composition reference data for infants, children, and adolescents. Adv Nutr. 2014;5(3):320S-9S.

38. Weber DR, Moore RH, Leonard MB, Zemel BS. Fat and lean BMI reference curves in children and adolescents and their utility in identifying excess adiposity compared with BMI and percentage body fat. Am J Clin Nutr. 2013;98(1):49-56.

39. Vanltallie TB, Yang MU, Heymsfield SB, Funk RC, Boileau RA. Heightnormalized indices of the body's fat-free mass and fat mass: potentially useful indicators of nutritional status. Am J Clin Nutr. 1990:52(6):953-9.

40. Wells JC, Cole TJ. Adjustment of fat-free mass and fat mass for height in children aged 8 y. Int J Obes Relat Metab Disord. 2002;26(7):947-52.

41. Liu P, Ma F, Lou H, Liu Y. The utility of fat mass index vs. body mass index and percentage of body fat in the screening of metabolic syndrome. BMC Public Health. 2013;13:629.

42. Peltz G, Aguirre MT, Sanderson M, Fadden MK. The role of fat mass index in determining obesity. Am J Hum Biol. 2010;22(5):639-47.

43. Andersen GS, Girma T, Wells JC, Kaestel P, Leventi M, Hother AL, et al. Body composition from birth to 6 mo of age in Ethiopian infants: reference data obtained by air-displacement plethysmography. Am J Clin Nutr. 2013;98(4):885-94

44. Frondas-Chauty A, Louveau I, Le Huerou-Luron I, Roze JC, Darmaun D. Airdisplacement plethysmography for determining body composition in neonates: validation using live piglets. Pediatr Res. 2012:72(1):26-31.

45. Ellis KJ, Yao M, Shypailo RJ, Urlando A, Wong WW, Heird WC. Body-composition assessment in infancy: air-displacement plethysmography compared with a reference 4-compartment model. Am J Clin Nutr. 2007:85(1):90-5.

46. Wells JCK, Fewtrell MS. Measuring body composition. Arch Dis Child. 2006; 91(7):612-7.

47. Davies PS, Wells JC Calculation of total body water in infancy. Eur J Clin Nutr. 1994;48(7):490-5.

48. Bland JM, Altman DG. Statistical methods for assessing agreement between two methods of clinical measurement. Lancet. 1986;1(8476):307-10. 
49. Fields DA, Demerath EW, Pietrobelli A, Chandler-Laney PC. Body composition at 6 months of life: comparison of air displacement plethysmography and dual-energy X-ray absorptiometry. Obesity (Silver Spring). 2012;20(11):2302-6.

50. Roggero P, Gianni ML, Amato O, Piemontese P, Morniroli D, Wong WW, et al. Evaluation of air-displacement plethysmography for body composition assessment in preterm infants. Pediatr Res. 2012;72(3):316-20.

51. Forsum E, Olhager E, Törnqvist $C$. An evaluation of the pea pod system for assessing body composition of moderately premature infants. Nutrients. 2016;8(4):238.

52. Au CP, Raynes-Greenow CH, Turner RM, Carberry AE, Jeffery HE. Body composition is normal in term infants born to mothers with well-controlled gestational diabetes mellitus. Diabetes Care. 2013;36(3):562-4.

53. Donnelley EL, Raynes-Greenow CH, Turner RM, Carberry AE, Jeffery HE. Antenatal predictors and body composition of large-for-gestational-age newborns: perinatal health outcomes. J Perinatol. 2014;34(9):698-704.

54. Gianni ML, Roggero P, Morlacchi L, Garavaglia E, Piemontese P, Mosca F. Formula-fed infants have significantly higher fat-free mass content in their bodies than breastfed babies. Acta Paediatr. 2014;103(7):e277-81.

55. Gianni ML, Roggero P, Taroni F, Liotto N, Piemontese P, Mosca F. Adiposity in small for gestational age preterm infants assessed at term equivalent age. Arch Dis Child Fetal Neonatal Ed. 2009;94(5): F368-72.

56. Hull HR, Dinger MK, Knehans AW, Thompson DM, Fields DA. Impact of maternal body mass index on neonate birthweight and body composition. Am J Obstet Gynecol. 2008;198(4):416 e1-6.

57. Josefson JL, Zeiss DM, Rademaker AW, Metzger BE. Maternal leptin predicts adiposity of the neonate. Horm Res Paediatr. 2014;81(1):13-9.

58. Lampl M, Lee W, Koo W, Frongillo EA, Barker DJ, Romero R. Ethnic differences in the accumulation of fat and lean mass in late gestation. Am J Hum Biol. 2012;24(5):640-7.

59. Law $T L$, Korte JE, Katikaneni LD, Wagner $C L$, Ebeling MD, Newman RB. Ultrasound assessment of intrauterine growth restriction: relationship to neonatal body composition. Am J Obstet Gynecol. 2011;205(3):255 e1-6

60. Lee W, Balasubramaniam M, Deter RL, Hassan SS, Gotsch F, Kusanovic JP, et al. Fetal growth parameters and birth weight: their relationship to neonatal body composition. Ultrasound Obstet Gynecol. 2009;33(4):441-6.

61. Paviotti G, De Cunto A, Travan L, Bua J, Cont G, Demarini S. Longitudinal growth and body composition of twins versus singletons in the first month of life. Sci World J. 2013;2013:108189.

62. Stanfield KM, Wells JC, Fewtrell MS, Frost C, Leon DA. Differences in body composition between infants of south Asian and European ancestry: the London mother and baby study. Int J Epidemiol. 2012;41(5):1409-18.

63. De Cunto A, Paviotti G, Travan L, Bua J, Cont G, Demarini S. Impact of surgery for neonatal gastrointestinal diseases on weight and fat mass. J Pediatr. 2015;167(3):568-71.

64. Roggero P, Gianni ML, Forzenigo L, Tondolo T, Taroni F, Liotto N, et al. No relative increase in intra-abdominal adipose tissue in healthy unstressed preterm infants at term. Neonatology. 2015;107(1):14-9.

65. Ramel SE, Gray HL, Ode KL, Younge N, Georgieff MK, Demerath EW. Body composition changes in preterm infants following hospital discharge: comparison with term infants. J Pediatr Gastroenterol Nutr. 2011;53(3):333-8

66. Bartok CJ. Babies fed breastmilk by breast versus by bottle: a pilot study evaluating early growth patterns. Breastfeed Med. 2011;6(3):117-24.

67. Rudolph MC, Young BE, Lemas DJ, Palmer CE, Hernandez TL, Barbour LA, et al. Early infant adipose deposition is positively associated with the $n-6$ to $\mathrm{n}-3$ fatty acid ratio in human milk independent of maternal BMI. Int J Obes (2005). 2017:41(4):510-7.

68. Giannì ML, Consonni D, Liotto N, Roggero $\mathrm{P}$, Morlacchi L, Piemontese $\mathrm{P}$, et al. Does human milk modulate body composition in late preterm infants at term-corrected age? Nutrients. 2016;8(10):664.

69. Breij LM, Mulder MT, van Vark-van der Zee LC, Hokken-Koelega ACS. Appetiteregulating hormones in early life and relationships with type of feeding and body composition in healthy term infants. Eur J Nutr. 2017;56(4):1725-32.

70. Andres A, Gomez-Acevedo H, Badger TM. Quantitative nuclear magnetic resonance to measure fat mass in infants and children. Obesity (Silver Spring). 2011;19(10):2089-95.

71. Aris IM, Soh SE, Tint MT, Liang S, Chinnadurai A, Saw SM, et al. Body fat in Singaporean infants: development of body fat prediction equations in Asian newborns. Eur J Clin Nutr. 2013;67(9):922-7.
72. Carberry AE, Raynes-Greenow CH, Turner RM, Jeffery HE. Customized versus population-based birth weight charts for the detection of neonatal growth and perinatal morbidity in a cross-sectional study of term neonates. Am J Epidemiol. 2013;178(8):1301-8

73. Law TL, Katikaneni LD, Taylor SN, Korte JE, Ebeling MD, Wagner CL, et al. Customized versus population-based growth curves: prediction of low body fat percent at term corrected gestational age following preterm birth. J Matern Fetal Neonatal Med. 2012;25(7):1142-7.

74. Lingwood BE, Storm Van Leeuwen AM, Carberry AE, Fitzgerald EC, Callaway LK, Colditz PB, et al. Prediction of fat-free mass and percentage of body fat in neonates using bioelectrical impedance analysis and anthropometric measures: validation against the PEA POD. Br J Nutr. 2012;107(10):1545-52.

75. Cauble JS, Dewi M, Hull HR. Validity of anthropometric equations to estimate infant fat mass at birth and in early infancy. BMC Pediatr. 2017;17:88.

76. Villar J, Puglia FA, Fenton TR, Cheikh Ismail L, Staines-Urias E, Giuliani F, et al. Body composition at birth and its relationship with neonatal anthropometric ratios: the newborn body composition study of the INTERGROWTH-21(st) project. Pediatr Res. 2017;82(2):305-16.

77. Gianni ML, Roggero P, Liotto N, Amato O, Piemontese P, Morniroli D, et al. Postnatal catch-up fat after late preterm birth. Pediatr Res. 2012;72(6):637-40.

78. Roggero P, Gianni ML, Orsi A, Piemontese P, Amato O, Moioli C, et al. Neonatal period: body composition changes in breast-fed full-term newborns. Neonatology. 2010;97(2):139-43.

79. Roggero P, Gianni ML, Liotto N, Taroni F, Orsi A, Amato O, et al. Rapid recovery of fat mass in small for gestational age preterm infants after term. PLoS One. 2011;6(1):e14489.

80. Carberry AE, Colditz PB, Lingwood BE. Body composition from birth to 4.5 months in infants born to non-obese women. Pediatr Res. 2010;68(1):84-8

81. Shapiro ALB, Boyle KE, Dabelea D, Patinkin ZW, De la Houssaye B, Ringham BM, et al. Nicotinamide promotes Adipogenesis in umbilical cord-derived mesenchymal stem cells and is associated with neonatal adiposity: the healthy start BabyBUMP project. PLoS One. 2016;11(7): e0159575.

82. Shapiro ALB, Kaar JL, Crume TL, Starling AP, Siega-Riz AM, Ringham BM, et al. Maternal diet quality in pregnancy and neonatal adiposity: the healthy start study. Inter J Obes (2005). 2016;40(7):1056-62.

83. Kizirian NV, Markovic TP, Muirhead R, Brodie S, Garnett SP, Louie JCY, et al. Macronutrient balance and dietary glycemic index in pregnancy predict neonatal body composition. Nutrients. 2016;8(5):270.

84. Castro NP, Euclydes W, Simões FA, Vaz-de-Lima LRA, De Brito CA, Luzia LA, et al. The relationship between maternal plasma leptin and adiponectin concentrations and newborn adiposity. Nutrients. 2017;9(3):182.

85. Lemas DJ, Young BE, Baker PR, Tomczik AC, Soderborg TK, Hernandez TL, et al. Alterations in human milk leptin and insulin are associated with early changes in the infant intestinal microbiome. Am J Clin Nutr. 2016;103(5):1291-300.

86. MacDonald TM, Hui L, Tong S, Robinson AJ, Dane KM, Middleton AL, et al. Reduced growth velocity across the third trimester is associated with placental insufficiency in fetuses born at a normal birthweight: a prospective cohort study. BMC Med. 2017;15:164.

87. Piyasena C, Cartier J, Provençal N, Wiechmann T, Khulan B, Sunderasan R, et al. Dynamic changes in dna methylation occur during the first year of life in preterm infants. Front Endocrinol. 2016;7:158

88. Andersen GS, Girma T, Wells JC, Kaestel P, Michaelsen KF, Friis H. Fat and fat-free mass at birth: air displacement plethysmography measurements on 350 Ethiopian newborns. Pediatr Res. 2011;70(5):501-6.

89. Au CP, Raynes-Greenow CH, Turner RM, Carberny AE, Jeffery H. Fetal and maternal factors associated with neonatal adiposity as measured by air displacement plethysmography: a large cross-sectional study. Early Hum Dev. 2013:89(10):839-43.

90. Carberry AE, Raynes-Greenow CH, Turner RM, Askie LM, Jeffery HE. Is body fat percentage a better measure of undernutrition in newborns than birth weight percentiles? Pediatr Res. 2013;74(6):730-6.

91. Eriksson B, Lof M, Forsum E. Body composition in full-term healthy infants measured with air displacement plethysmography at 1 and 12 weeks of age. Acta Paediatr. 2010;99(4):563-8.

92. Estampador AC, Pomeroy J, Renstrom F, Nelson SM, Mogren I, Persson M, et al. Infant body composition and adipokine concentrations in relation to maternal gestational weight gain. Diabetes Care. 2014;37(5):1432-8.

93. Fields DA, Gilchrist JM, Catalano PM, Gianni ML, Roggero PM, Mosca F. Longitudinal body composition data in exclusively breast-fed infants: a multicenter study. Obesity (Silver Spring). 2011;19(9):1887-91. 
94. Henriksson P, Lof M, Forsum E. Glucose homeostasis variables in pregnancy versus maternal and infant body composition. Nutrients. 2015;7(7):5615-27.

95. Henriksson P, Lof M, Forsum E. Parental fat-free mass is related to the fatfree mass of infants and maternal fat mass is related to the fat mass of infant girls. Acta Paediatr. 2015;104(5):491-7.

96. Josefson JL, Feinglass J, Rademaker AW, Metzger BE, Zeiss DM, Price HE, et al. Maternal obesity and vitamin D sufficiency are associated with cord blood vitamin D insufficiency. J Clin Endocrinol Metab. 2013:98(1):114-9.

97. Josefson $J$, Hoffmann JA, Metzger BE. Excessive weight gain in women with a normal pre-pregnancy BMl is associated with increased neonatal adiposity. Pediatr Obes. 2013;8(2):e33-6.

98. Lee W, Riggs $T$, Koo W, Deter RL, Yeo L, Romero R. The relationship of newborn adiposity to fetal growth outcome based on birth weight or the modified neonatal growth assessment score. J Matern Fetal Neonatal Med. 2012;25(10):1933-40.

99. Moyer-Mileur $\amalg$, Slater H, Thomson JA, Mihalopoulos N, Byrne J, Varner MW. Newborn adiposity measured by plethysmography is not predicted by late gestation two-dimensional ultrasound measures of fetal growth. J Nutr. 2009;139(9):1772-8.

100. Ode KL, Gray HL, Ramel SE, Georgieff MK, Demerath EW. Decelerated early growth in infants of overweight and obese mothers. J Pediatr. 2012:161(6):1028-34.

101. Hawkes CP, Hourihane JOB, Kenny LC, Irvine AD, Kiely M, Murray DM. Gender- and gestational age-specific body fat percentage at birth. Pediatrics. 2011;128(3):e645-51.

102. Starling AP, Brinton JT, Glueck DH, Shapiro AL, Harrod CS, Lynch AM, et al. Associations of maternal $\mathrm{BMI}$ and gestational weight gain with neonatal adiposity in the healthy start study. Am J Clin Nutr. 2015;101(2):302-9.

103. Pereira-da-Silva L, Cabo C, Moreira AC, Virella D, Guerra T, Camoes T, et al. The adjusted effect of maternal body mass index, energy and macronutrient intakes during pregnancy, and gestational weight gain on body composition of full-term neonates. Am J Perinatol. 2014;31(10):875-82.

104. Pereira-da-Silva L, Cabo C, Moreira AC, Papoila AL, Virella D, Neves R, et al. The effect of long-chain polyunsaturated fatty acids intake during pregnancy on adiposity of healthy full-term offspring at birth. J Perinatol. 2015;35(3):177-80.

105. Sauder KA, Koeppen HJ, Shapiro ALB, Kalata KE, Stamatoiu AV, Ringham BM, et al. Prenatal vitamin d intake, cord blood 25-hydroxyvitamin d, and offspring body composition: the healthy start study. Nutrients. 2017:9(7):790.

106. Josefson JL, Simons H, Zeiss DM, Metzger BE. Excessive gestational weight gain in the first trimester among women with normal glucose tolerance and resulting neonatal adiposity. J Perinatol. 2016;36(12):1034-8.

107. Meyers JM, Greecher CP, Shaffer ML, Shenberger JS. Potential influence of total parenteral nutrition on body composition at discharge in preterm infants. J Matern Fetal Neonatal Med. 2013;26(15):1548-53.

108. Ramel SE, Gray HL, Davern BA, Demerath EW. Body composition at birth in preterm infants between 30 and 36 weeks gestation. Pediatr Obes. 2015; 10(1):45-51.

109. Roggero P, Gianni ML, Amato O, Liotto N, Morlacchi L, Orsi A, et al. Growth and fat-free mass gain in preterm infants after discharge: a randomized controlled trial. Pediatrics. 2012;130(5):e1215-21.

110. Roggero P, Gianni ML, Amato O, Orsi A, Piemontese P, Puricelli V, et al. Influence of protein and energy intakes on body composition of formula-fed preterm infants after term. J Pediatr Gastroenterol Nutr. 2008;47(3):375-8.

111. Roggero P, Gianni ML, Orsi A, Amato O, Piemontese P, Liotto N, et al. Implementation of nutritional strategies decreases postnatal growth restriction in preterm infants. PLoS One. 2012;7(12):e51166.

112. Simon L, Frondas-Chauty A, Senterre T, Flamant C, Darmaun D, Roze JC. Determinants of body composition in preterm infants at the time of hospital discharge. Am J Clin Nutr. 2014;100(1):98-104.

113. Olhager $E$, Tornqvist $C$. Body composition in late preterm infants in the first 10 days of life and at full term. Acta Paediatr. 2014;103(7):737-43.

114. Simon L, Borrego P, Darmaun D, Legrand A, Roze JC, Chauty-Frondas A. Effect of sex and gestational age on neonatal body composition. Br J Nutr. 2013:109(6):1105-8.

115. Crume TL, Shapiro AL, Brinton JT, Glueck DH, Martinez M, Kohn M, et al. Maternal fuels and metabolic measures during pregnancy and neonatal body composition: the healthy start study. J Clin Endocrinol Metab. 2015; 100(4):1672-80

116. Harrod CS, Fingerlin TE, Chasan-Taber L, Reynolds RM, Glueck DH, Dabelea D. Exposure to prenatal smoking and early-life body composition: the healthy start study. Obesity (Silver Spring). 2015;23(1):234-41.
117. Harrod CS, Reynolds RM, Chasan-Taber L, Fingerlin TE, Glueck DH, Brinton JT, et al. Quantity and timing of maternal prenatal smoking on neonatal body composition: the healthy start study. J Pediatr. 2014;165(4):707-12.

118. Henriksson $P$, Lof $M$, Soderkvist $P$, Forsum $E$. Variation in the fat mass and obesity-related (FTO) genotype is not associated with body fatness in infants, but possibly with their length. Pediatr Obes. 2014;9(5):e112-5.

119. O'Donovan SM, Murray DM, Hourihane JOB, Kenny LC, Irvine AD, Kiely M. Cohort profile: the Cork BASELINE birth cohort study: babies after SCOPE: evaluating the longitudinal impact on neurological and nutritional endpoints. Inter J Epidemiol. 2015;44(3):764-75.

120. Starling AP, Shapiro ALB, Sauder KA, Kaar JL, Ringham BM, Glueck DH, et al. Blood pressure during pregnancy, neonatal size and altered body composition: the healthy start study. J Perinatol. 2017;37(5):502-6.

121. Fields DA, Higgins PB, Hunter GR. Assessment of body composition by airdisplacement plethysmography: influence of body temperature and moisture. Dyn Med. 2004;3(1):3.

122. Higgins PB, Fields DA, Hunter GR, Gower BA. Effect of scalp and facial hair on air displacement plethysmography estimates of percentage of body fat. Obes Res. 2001;9(5):326-30.

123. Gianni ML, Roggero P, Piemontese P, Morlacchi L, Bracco B, Taroni F, et al. Boys who are born preterm show a relative lack of fat-free mass at 5 years of age compared to their peers. Acta Paediatr. 2015;104(3):e119-23.

124. Rosendale RP, Bartok CJ. Air-displacement plethysmography for the measurement of body composition in children aged 6-48 months. Pediatr Res. 2012;71(3):299-304.

125. Dempster P, Aitkens S. A new air displacement method for the determination of human body composition. Med Sci Sports Exerc. 1995; 27(12):1692-7.

126. Higgins PB, Silva AM, Sardinha LB, Hull HR, Goran MI, Gower BA, et al. Validity of new child-specific thoracic gas volume prediction equations for air-displacement plethysmography. BMC Pediatr. 2006;6(1):1-8.

127. Fields DA, Hull HR, Cheline AJ, Yao M, Higgins PB. Child-specific thoracic gas volume prediction equations for air-displacement plethysmography. Obes Res. 2004;12(11):1797-804.

128. Collins AL, McCarthy HD. Evaluation of factors determining the precision of body composition measurements by air displacement plethysmography. Eur J Clin Nutr. 2003:57(6):770-6.

129. Fomon SJ, Haschke F, Ziegler EE, Nelson SE. Body composition of reference children from birth to age 10 years. Am J Clin Nutr. 1982;35(5 Suppl):1169-75

130. Butte NF, Hopkinson JM, Wong WW, Smith EO, Ellis KJ. Body composition during the first 2 years of life: an updated reference. Pediatr Res. 2000;47(5): 578-85.

131. Rodriguez G, Ventura P, Samper MP, Moreno L, Sarria A, Perez-Gonzalez JM. Changes in body composition during the initial hours of life in breast-fed healthy term newborns. Biol Neonate. 2000;77(1):12-6.

\section{Submit your next manuscript to BioMed Central and we will help you at every step:}

- We accept pre-submission inquiries

- Our selector tool helps you to find the most relevant journal

- We provide round the clock customer support

- Convenient online submission

- Thorough peer review

- Inclusion in PubMed and all major indexing services

- Maximum visibility for your research

Submit your manuscript at www.biomedcentral.com/submit
) Biomed Central 